\title{
Influence of Gamification on Students' Motivation in using E-Learning Applications Based on the Motivational Design Model
}

\author{
http://dx.doi.org/10.3991/ijet.v10i2.4355
}

\author{
W. M. Amir Fazamin W. Hamzah ${ }^{1}$, Noraida Haji Ali ${ }^{1}$, Md. Yazid Mohd Saman ${ }^{1}$, \\ Mohd Hafiz Yusoff ${ }^{1}$, and Azliza Yacob ${ }^{2}$ \\ ${ }^{1}$ Universiti Malaysia Terengganu, Terengganu, Malaysia \\ 2 TATi University College, Terengganu, Malaysia
}

\begin{abstract}
Students' motivation is an important factor in ensuring the success of e-learning implementation. In order to ensure students is motivated to use e-learning, motivational design has been used during the development process of e-learning applications. The use of gamification in learning context can help to increase student motivation. The ARCS+G model of motivational design is used as a guide for the gamification of learning. This study focuses on the influence of gamification on students' motivation in using elearning applications based on the ARCS+G model. Data from the Instructional Materials Motivation Scale (IMMS) questionnaire, were gathered and analyzed for comparison of two groups (one control and one experimental) in attention, relevance, confidence, and satisfaction categories. Based on the result of analysis, students from the experimental group are more motivated to use e-learning applications compared with the controlled group. This proves that gamification affect students' motivation when used in elearning applications.
\end{abstract}

Index Terms-Gamification, Motivational Design, ARCS Model, ARCS+G Model.

\section{INTRODUCTION}

Gamification is defined as the use of game mechanics in the non-game context to change the behaviour of people [1]. Gamification is the tactics used to contribute motivation principles and engagement based on the gaming concept into ordinary activities. According to Nah et al. [2], one of the techniques can be used to motivate students are by integrating gamification into learning. Gamification of learning is another way to use game dynamics and game mechanics in education. Encourage unmotivated students to become more involved in the process of learning and interacting with other students can be done by adding simple game features in learning. The use of gamification in the learning context can help to increase student motivation [3]. In previous studies, we have proposed the gamification incorporated with the ARCS model of motivational design called $\mathrm{ARCS}+\mathrm{G}$ model [4]. This model is intended as a guide for applying gamification of learning.

Previous research stated the lack of students' motivation in the use of e-learning applications is one of the reasons why e-learning is not successful or do not achieve the desired goal [5]-[8]. There are many factors that affect motivation in e-learning. Student engagement is the primary mechanism that enables motivational processes to contribute to e-learning and development [9],[10]. Meanwhile, Priego \& Peralta [7] states that student engagement is a capital aspect to succeed in any online formative ac- tivities. According to El-seoud et al. [5], an interactive feature of e-learning is also the factor of increases the motivation of students. Based on above-mentioned facts, it may be concluded that it is worth studying the students' motivation on e-learning applications. Until now, investigations of the influence of gamification on students' motivation in using e-learning applications based on motivational design models have not been carried out widely [11].

Even though a lot of work has been reported on gamification of learning, very little work has been reported on the motivation based on the gamification of learning. The objective of this paper is to access and examine the influence of gamification on students' motivation in using elearning applications based on the ARCS $+\mathrm{G}$ model. Following this objective, two specific Research Questions (RQ) are proposed:

1. Do e-learning applications use in this study produce statistically significant differences between the controlled group, and the experimental group in terms of students' motivation as measured by the overall summative score of the Instructional Materials Motivation Survey (IMMS)?

2. Do e-learning applications use in this study produce statistically significant differences between the controlled group, and the experimental group in terms of students' motivation based on the use of gamification?

\section{LITERATURE REVIEW}

\section{A. Gamification}

The gamification element is derived from the MDA framework, which based on game design theory [12],[13]. There are three components of the MDA Framework, namely: Mechanics is related to games that describe the specific components of the game at the data representation level and algorithms; Dynamics is about the run-time mechanic's behaviour acting on the player inputs and the other outputs over time; and Aesthetics describes the emotional response desired by the player when the player interacts with the game system [14]. Table 1 shows the components of MDA Framework.

\section{B. Motivational Design}

Motivation can be defined as the extent to which constant effort is directed towards a goal [15]. Intrinsic motivation can be determined by the individual and externally 
TABLE I. THE COMPONENTS OF MDA FRAMEWORK

\begin{tabular}{|l|l|l|}
\hline \multicolumn{1}{|c|}{ Game mechanics } & \multicolumn{1}{|c|}{ Game dynamics } & \multicolumn{1}{c|}{ Aesthetics } \\
\hline Points & Reward & \\
Levels & Status & Satisfaction \\
Challenges & Achievement & Pleasure \\
Virtual Goods & Self-Expression & Envy \\
Leader-Boards & Competition & Respect \\
Badges & Connection. \\
Gifts and Charity & & \\
\hline
\end{tabular}

by sources as conditional variables and environmental factors [16]. Motivational features can sometimes be rewards or fun activities; however, they are not effective unless they participate the learner in the content and instructional goal. According to Malone [17], the teachers can provide extrinsic rewards for achievement or effortful behaviour by introducing fun activities. By creating the enhanced motivation and attribute for some students, better behaviour can be derived from the design of motivation, particularly when motivated designers to focus on the skills development in self-motivation and selfregulation in learners [18].

Motivational design is the process of organizing resources and methods to lead about motivation changes. According to Keller [19], motivational design can be used to enhance motivation to learn, motivation to work, developing of particular motivational attributes and an enhancement of people's motivation skills in self-motivation. The processes and techniques for effective and efficient teaching refers to instructional design in the traditional view. The economy in the use of instructional time, student time, materials and other resources is referred to efficiency. Meanwhile, effectiveness sometimes includes motivation.

\section{C. $A R C S+G$ Model}

The ARCS motivational design model is developed by John Keller to explain motivation [20]-[22]. The use of this model is to assess motivational stimuli for learners' motivation and performance. There are four main categories in the ARCS model: attention, relevance, confidence, and satisfaction. The ARCS model has a design that can be customized with a variety of learning conditions, and can be expanded according to the desired requirements.

The primary elements in the interaction of human desire and game play [23] is taken into the $\mathrm{ARCS}+\mathrm{G}$ model. The gamification elements used in incorporated with the ARCS model are based on the game dynamics such as reward, status, competition, achievement, self-expression, and altruism. In specific, the game dynamics in the $\mathrm{ARCS}+\mathrm{G}$ model involves the construction of rules that encourage users to explore and learn the properties of learning. The game mechanics are intended to encourage determined emotions in the user through game dynamics that promote the desires and motivations leading to those emotions. In this model, gamification elements added in the categories of confidence and satisfaction based on the ARCS model. The descriptions of the ARCS $+\mathrm{G}$ model is shown in the Table 2.

\section{Methodology}

\section{A. Design}

This study design was the true experimental by using Posttest design. A set of questionnaires available for data collection purposes. Questionnaires were used to collect information on the students' motivation related to the study. Questionnaire method was used because of the advantages obtained the required data can be obtained directly from the questionnaire, a short response time and facilitate the respondents to answer.

\section{B. Participant}

Population was about the 25 of Form Six students of a school and 24 of them were the respondents. The basis for determining the amount of the sample was based on the Table for Determining Sample Size Krejcie and Morgan [24]. They set the minimum total samples should be based on the total population. Based on that table, the minimum number of samples that need to take from 25 populations were 24 respondents. Respondents for the study randomly chosen stratified without taking into account factors like.sex and computer knowledge. Students were randomly chosen and divided into two groups, the experimental group and the controlled group. The experimental group has 12 students, and the controlled group has 12 students.

\section{Instruments}

Instructional Materials Motivation Survey (IMMS) questionnaire was used to measure students' motivational reactions to self-directed instructional materials. IMMS was not intended to measure student's generalized levels of

\section{TABLE II. THE DESCRIPTIONS OF THE ARCS+G MODEL}

\begin{tabular}{|c|c|c|}
\hline Categories & Sub-categories & Descriptions \\
\hline \multirow[t]{3}{*}{ Attention } & Perceptual Arousal & - Capturing learner interest. \\
\hline & Inquiry Arousal & - Stimulating interest using e-learning material. \\
\hline & Variability & - Maintaining learner attention. \\
\hline \multirow[t]{3}{*}{ Relevance } & Goal Orientation & - Meeting learner needs and know their needs. \\
\hline & Motive Matching & - Linking e-learning material with learner personal interest. \\
\hline & Familiarity & - Fixing e-learning material to learner experiences. \\
\hline \multirow[t]{6}{*}{ Confidence } & Learning Requirements & - Building positive expectations for success when using e-learning material. \\
\hline & Success Opportunities & - Using e-learning material support or enhance the competency of learners. \\
\hline & Personal Responsibility & - Linking e-learning success to personal effort and ability. \\
\hline & Reward & $\begin{array}{l}\text { - Something of value will be given to people who do activities with the intent to cause the behaviour to occur } \\
\text { again. }\end{array}$ \\
\hline & Status & - Conditions where to show status or recognition has been achieved. \\
\hline & Competition & - Enable people to challenge each other to get the high score at some activity. \\
\hline \multirow[t]{6}{*}{ Satisfaction } & Intrinsic reinforcement & - Encouraging and supporting the learner intrinsic enjoyment of the e-learning experience. \\
\hline & Extrinsic Rewards & - Providing positive reinforcement to the learner success with e-learning. \\
\hline & Equity & - Convincing the learner to fair treatment. \\
\hline & Achievement & - Achievement tends to encourage students to seek challenges and setting goals. \\
\hline & Self-expression & - Self-expression is used to mark him or herself as having a unique personality of those around them. \\
\hline & Altruism & - Be generous with giving gifts is a strong motivation to develop an ongoing relationship. \\
\hline
\end{tabular}


motivation toward school learning (i.e. they were not traitor construct-type measures). The goal of instruments was to find out how motivated students were, or expect to be, by a particular course. There were 36 statements in this questionnaire. Each of the statement has a relationship to the instructional materials studied. This survey uses a Likert-type scale with five possible choices: (1) Not true, (2) Slightly true, (3) Moderately true, (4) Mostly true, and (5) Very true. Four factor scores were averaged to construct an overall motivation score. Reliability estimate for motivational scales based on Cronbach's coefficient alpha was computed for each of the four factors and the overall score. The Mann-Whitney $U$ test used for comparison, the mean of two independent groups (control and experimental).

\section{Procedures}

According to Keller [21], the excessive motivational tactics in computer-based teaching proved to disrupt the already motivated students. Keller [25] also suggested that motivational strategies not exceedingly time-consuming, work within the delivery system, and be presented in an acceptable way to participants. The student from the controlled group was given a week to use ARCS-based elearning applications. Meanwhile, the students of the experimental group was given the same time to use the ARCS + G-based e-learning applications. Subsequently, they will be given an IMMS questionnaire to measure the four factors (attention, relevance, confidence, and satisfac- tion) of the ARCS model as well as an overall motivation score. The data were analysed using Statistical Package for Social Science version 21.0 (SPSS 21.0).

\section{E. Materials}

In general, two e-learning applications have been developed. For the controlled group, e-learning applications has been developed based on the ARCS model. While for the experimental group, e-learning applications has been developed based on the $\mathrm{ARCS}+\mathrm{G}$ model. Both have been used motivational strategies/tactics to stimulate curiosity, illustrate the practical relevance of the content, build confidence, and provide satisfying outcomes. However, for the experimental group, gamification elements have been used to guide the development of motivational characteristics in relation to the beginning, the middle, and the end of e-learning applications. At the beginning of the learning applications, it contains the main page, menu and guidelines; in the middle has been made up of learning content and questions; at the end, it consists of results and feedback. The motivational design for e-learning applications using $\mathrm{ARCS}+\mathrm{G}$ model was represented in a matrix (Table $3)$. The first column consists of the list of ARCS $+\mathrm{G}$ categories. The second column contains the sub-categories of each $\mathrm{ARCS}+\mathrm{G}$ categories. The third column shows process questions, the types of strategies/tactics to use will be decided. The fourth column explains the strategies/tactics used in the gamification of learning.

TABLE III

THE MOTIVATIONAL DESIGN FOR E-LEARNING APPLICATIONS

\begin{tabular}{|c|c|c|c|}
\hline Categories & Sub-categories & Process questions & Strategies/tactics \\
\hline \multirow[t]{3}{*}{ Attention } & $\begin{array}{l}\text { Perceptual Arous- } \\
\text { al }\end{array}$ & $\begin{array}{l}\text { What can I do to capture the learners' } \\
\text { interest? }\end{array}$ & $\begin{array}{l}\text { - Use interesting image } \\
\text { - Use animation } \\
\text { - Maximize visibility }\end{array}$ \\
\hline & Inquiry Arousal & $\begin{array}{l}\text { How can I stimulate interest using this } \\
\text { e-learning applications? }\end{array}$ & $\begin{array}{l}\text { - Create interactive e-learning applications } \\
\text { - The interface should be easy to navigate } \\
\text { - Balance aesthetics, usability and visibility }\end{array}$ \\
\hline & Variability & $\begin{array}{l}\text { How can I maintain the learners' atten- } \\
\text { tion? }\end{array}$ & $\begin{array}{l}\text { - Put information first } \\
\text { - Use attractive interface } \\
\text { - Use up-to-date content }\end{array}$ \\
\hline \multirow[t]{3}{*}{ Relevance } & Goal Orientation & $\begin{array}{l}\text { How can I meet learners' need? } \\
\text { Do I know their needs? }\end{array}$ & $\begin{array}{l}\text { - Conduct need assessment } \\
\text { - Determine the goal }\end{array}$ \\
\hline & Motive Matching & $\begin{array}{l}\text { How can I link e-learning applications } \\
\text { with learner's personal interest? }\end{array}$ & $\begin{array}{l}\text { - Look at the learners' point of view } \\
\text { - Make learners as a partner in the development process }\end{array}$ \\
\hline & Familiarity & $\begin{array}{l}\text { How can I tie the e-learning applications } \\
\text { to the learners' experiences? }\end{array}$ & $\begin{array}{l}\text { - Use subject matter experts } \\
\text { - Modify existing e-learning applications } \\
\end{array}$ \\
\hline \multirow[t]{6}{*}{ Confidence } & $\begin{array}{l}\text { Learning Re- } \\
\text { quirements }\end{array}$ & $\begin{array}{l}\text { How can I build positive expectations } \\
\text { for success when using e-learning } \\
\text { applications? }\end{array}$ & $\begin{array}{l}\text { - Train learners to use e-learning applications } \\
\text { - Let learners know what is expected of them }\end{array}$ \\
\hline & $\begin{array}{l}\text { Success Opportu- } \\
\text { nities }\end{array}$ & $\begin{array}{l}\text { How will using e-learning applications } \\
\text { support or enhance the competency of } \\
\text { learners? }\end{array}$ & $\begin{array}{l}\text { - Provide situations for learners to experience success with e-learning } \\
\text { applications }\end{array}$ \\
\hline & $\begin{array}{l}\text { Personal Respon- } \\
\text { sibility }\end{array}$ & $\begin{array}{l}\text { How will learners know their success is } \\
\text { based on their efforts and abilities? }\end{array}$ & - Create e-learning applications that enable learners to self-monitor \\
\hline & Reward & How can learner get rewards? & - learners can claim rewards by using the point \\
\hline & Status & How can learners know their status? & $\begin{array}{l}\text { - Using levels to signify completion of intermediate goals in the e- } \\
\text { learning }\end{array}$ \\
\hline & Competition & How can learners compete? & $\begin{array}{l}\text { - Using leader-board to show the leading scorers of e-learning applica- } \\
\text { tions. }\end{array}$ \\
\hline \multirow[t]{6}{*}{ Satisfaction } & $\begin{array}{l}\text { Intrinsic rein- } \\
\text { forcement }\end{array}$ & $\begin{array}{l}\text { How can use of the e-learning applica- } \\
\text { tions be supported and encouraged? }\end{array}$ & - Provide feedback to show benefits of using e-learning applications \\
\hline & Extrinsic Rewards & $\begin{array}{l}\text { What will provide positive reinforce- } \\
\text { ment to the learners' successes with e- } \\
\text { learning applications? }\end{array}$ & - Give incentives to improve performance \\
\hline & Equity & $\begin{array}{l}\text { How can learners be convinced of fair } \\
\text { treatment? }\end{array}$ & $\begin{array}{l}\text { - Standardize scoring measurements for learner tasks and accomplish- } \\
\text { ments. }\end{array}$ \\
\hline & Achievement & How to show learner achievement? & $\begin{array}{l}\text { - Using badges to reward learners as well as recognize their achievement } \\
\text { and accomplishment. }\end{array}$ \\
\hline & Self-expression & $\begin{array}{l}\text { How learners can show their self- } \\
\text { expression? }\end{array}$ & - Using virtual goods such as clothing, weapons or jewellery. \\
\hline & Altruism & How can learners be altruism? & $\begin{array}{l}\text { - Giving a gift to other learners will pull the learner into the e-learning, } \\
\text { and then learners are motivated to send gifts to all learners. }\end{array}$ \\
\hline
\end{tabular}


By using this motivational design, the requirements of motivational features for e-learning applications have been determined. The list of motivational strategies/tactics have been used to guide the development of motivational features for e-learning applications. The developed elearning applications was a web-based, and integrated with Facebook as Facebook's apps. This was so that the elearning applications can be quickly disseminated to students, and can be monitored easily and effectively.

\section{RESUlT \& DiscUSSION}

\section{A. Research Question 1}

Analysis for each category of the ARCS was carried out, and overall scores were calculated. We count Cronbach's coefficient alpha for each factor as an estimate of reliability. The comparison results of the controlled group with the experimental group were shown in the Table 4.

The results from this study shown a statistically significant difference reliability estimates between the experimental and controlled groups in terms of the ARCS categories measured at IMMS. The overall reliability estimates value for the experimental group was .078 more than the controlled group. The experimental group has better reliability estimates in each category of the ARCS (attention, relevance, confidence, and satisfaction) than the controlled group. Therefore, these results have been answered for the Research Question 1. The e-learning applications use in this study produce statistically significant differences between the controlled group, and the experimental group in terms of students' motivation as measured by the overall summative score of the IMMS.

\section{B. Research Question 2}

In this study, for comparison, the mean of two independent groups, the Mann-Whitney $U$ test was used because the data type was ordinal. Although statistical power of non-parametric test Mann-Whitney $U$ was lower than the parametric test t-test, but the Mann-Whitney $U$ test was more robust when the assumption for the t-test was not met. Table 5 shows which group can be considered as having higher confidence and satisfaction, overall; namely, the group with the highest mean rank. In this case, the experimental group had the highest confidence and satisfaction.

Table 6 shows the actual significance value of the test. Specifically, the test statistics table provides the test statistic, U statistic, as well as the asymptotic significance (2tailed) $\mathrm{p}$-value. In the confidence category, the value of $\mathrm{Z}$ $=-2.558$ with the significant level at .011 (refer to line Asymp. Sig. (2-tailed). This result state the $\mathrm{p}$ value (.011) $<\alpha(.05)$. Whereas, in the satisfaction category, the value of $z=-2.707$ with the significant level at .007 . This result state the $p$ value $(.007)<\alpha(.05)$. Due to the $p$ value of the confidence and satisfaction in the experimental group was smaller than the alpha $(\alpha)$, it can be concluded that the category of confidence and satisfaction in the experimental group was statistically significantly higher than the control group. This difference was due to the use of gamification elements in the category of confidence and satisfaction based on the ARCS $+\mathrm{G}$ model. This proved that gamification influential on the students' motivation when used in e-learning applications. Therefore, the Research Question 2 has been answered that e-learning applications use in this study produce statistically significant differ-
TABLE IV

RELIABILITY ESTIMATES FOR MOTIVATIONAL SCALES USING CRONBACH'S COEFFICIENT ALPHA

\begin{tabular}{|l|c|c|}
\hline \multicolumn{1}{|c|}{ Category } & $\begin{array}{c}\text { Control Group } \\
\text { (ARCS Model) }\end{array}$ & $\begin{array}{c}\text { Experimental } \\
\text { Group } \\
\text { (ARCS+G Model) }\end{array}$ \\
\hline Attention (A) & .833 & .867 \\
Relevance (R) & .784 & .847 \\
Confidence (C) & .800 & .876 \\
Satisfaction (S) & .801 & .895 \\
\hline Total (ARCS) & .883 & .961 \\
\hline
\end{tabular}

TABLE V.

RANK

\begin{tabular}{|c|l|c|c|c|}
\hline Category & \multicolumn{1}{|c|}{ Group } & N & Mean Rank & Sum of Ranks \\
\hline Confidence & Control & 12 & 8.83 & 106.00 \\
& Experimental & 12 & 16.17 & 194.00 \\
& Total & 24 & & \\
\hline Satisfaction & Control & 12 & 8.63 & 103.50 \\
& Experimental & 12 & 16.38 & 196.50 \\
& Total & 24 & & \\
\hline
\end{tabular}

TABLE VI.

TEST STATISTICS

\begin{tabular}{|l|c|c|}
\hline & Confidence & Satisfaction \\
\hline Mann-Whitney U & 28.000 & 25.500 \\
\hline Wilcoxon W & 106.000 & 103.500 \\
\hline Z & -2.558 & -2.707 \\
\hline Asymp. Sig. (2-tailed) & .011 & .007 \\
\hline Exact Sig. [2*(1-tailed Sig.)] & .010 & .006 \\
\hline
\end{tabular}

ences between the controlled group, and the experimental group in terms of students' motivation based on the use of gamification.

\section{CONClusion}

The purpose of this study was to access and examine the influence of gamification on students' motivation in using e-learning applications based on the ARCS $+\mathrm{G}$ model. The advantages of the ARCS model that can be extended and proven successful in the increasing student motivation caused ARCS model was chosen as the basis to be expanded. The expanded model of the ARCS that incorporated with gamification called $A R C S+G$ model enabled the use of the game mechanics element in the motivational design for e-learning applications. The use of these elements in e-learning applications makes learning more interactive and attracts to students. The result shown the influential of gamification on the students' motivation in using ARCS+G-based e-learning applications. There were significant differences in the category of confidence and satisfaction in the comparison of the controlled group, and an experimental group. This because, the gamification elements in the category of confidence and satisfaction successfully engage and attract students in the use of elearning applications.

However, this study still has its limitation in the population sample, and analysis. This study simply includes Form Six students at a school that have only 24 respondents. Analysis was done on the reliability estimates for motivational scales using Cronbach's coefficient alpha and non-parametric test Mann-Whitney $U$. Further research maybe includes a larger population to obtain a sample of respondents more accurate. Analysis will be done by a variety of methods to determine the effect of gamification influence on students' motivation. 


\section{REFERENCES}

[1] S. Deterding, D. Dixon, R. Khaled and L. Nacke, "From Game Design Elements to Gamefulness: Defining Gamification ," Proceedings of MindTrek, pp. 9-15, 2011. http://dx.doi.org/10.1145/2181037.2181040

[2] F. F. Nah, V. R. Telaprolu, and S. Rallapalli, "Gamification of Education Using Computer Games Background," Gamification and Its Application to Education, pp. 99-107, 2013.

[3] J. J. Lee, T. College, D. Ph, E. Hammer, and M. Interdisciplinary, "Gamification in Education: What , How , Why Bother?," Academic Exchange Quarterly, vol. 15, pp. 1-5, 2011.

[4] W. M. A. F. W. Hamzah, N. H. Ali, M.Y.M. Saman, M.H. Yusoff and A. Yacob, "Enhancement of the ARCS Model for Gamification of Learning," 3rd International Conference on User Science and Engineering (i-USEr), pp. 287-291, 2-5 Sept. 2014.

[5] M. S. A. El-seoud, N. Seddiek, M. M. El-khouly, and A. Nosseir, "E-Learning and Students' Motivation: A Research Study on the Effect of E-Learning on Higher Education," International Journal of Emerging Technologies in Learning (IJET), pp. 20-26, 2009.

[6] M. Bang, K. Wohn, and C. Shi, "The Establishment of an eLearning System Based on SDT," International Journal of Emerging Technologies in Learning (IJET), vol. 9, no. 4, pp. 4349, 2014. http://dx.doi.org/10.3991/ijet.v9i4.3704

[7] R. G. Priego and A. Peralta, "Engagement factors and Motivation in E-Learning and Blended-Learning Projects," First International Conference on Technological Ecosystem for Enhancing Multiculturality (TEEM '13), 2013 http://dx.doi.org/10.1145/2536 536.2536606

[8] U. P. T. Maldonado, G. F. Khan, J. Moon, and J. J. Rho, "Elearning motivation and educational portal acceptance in developing countries," Online Information Review, vol. 35. pp. 66-85, 2011. http://dx.doi.org/10.1108/14684521111113597

[9] C. Furrer and E. Skinner, "Sense of relatedness as a factor in children's academic engagement and performance.," Journal of Educational Psychology, vol. 95. pp. 148-162, 2003. http://dx.doi.org/10.1037/0022-0663.95.1.148

[10] S. E. Bahji, Y. Lefdaoui, and J. El Alami, "Enhancing Motivation and Engagement: A Top-Down Approach for the Design of a Learning Experience According to the S2P-LM," International Journal of Emerging Technologies in Learning (IJET), vol. 8, no. 6, pp. 35-41, 2013. http://dx.doi.org/10.3991/ijet.v8i6.2955

[11] K. Erenli, "The Impact of Gamification," International Journal of Emerging Technologies in Learning (IJET), vol. 8, no. 1, pp. 1521, 2013.

[12] S. Deterding, M. Sicart, L. Nacke, K. O'Hara, and D. Dixon, "Gamification. using game-design elements in non-gaming contexts," Proc. 2011 Annu. Conf. Ext. Abstr. Hum. factors Comput. Syst. - CHI EA '11, p. 2425, 2011.

[13] G. Zicbermann and C. Cunningham, "Gamification by Design: Implementing Game Mechanics in Web and Mobile Apps," O'Reilly Media, Inc., First Edition, 2011.

[14] R. Hunicke, M. Leblanc, and R. Zubek, "MDA: A Formal Approach to Game Design and Game Research." Challenges in Game AI Workshop, Nineteenth National Conference on Artificial Intelligence, 2004.

[15] Campbell, J.P., Dunnette, M.D., Lawler, E.E., \& Weick, K.E. Managerial behavior, performance, and effectiveness. New York: McGraw-Hill, 1970.

[16] T. M. Amabile, K. G. Hill, B. A. Hennessey, and E. M. Tighe, "The Work Preference Inventory: assessing intrinsic and extrinsic motivational orientations.," J. Pers. Soc. Psychol., vol. 66, pp. 950-967, 1994. http://dx.doi.org/10.1037/0022-3514.66.5.950

[17] T. W. Malone and M. R. Lepper, "Making learning fun: A taxonomy of intrinsic motivations for learning," in Aptitude learning and instruction, vol. 3, pp. 223-253, 1987.

[18] J. M. Keller, "Motivational Design for Learning and Performance," pp. 21-42, 2010. http://dx.doi.org/10.1007/978-14419-1250-3 2

[19] J. M. Keller, "What Is Motivational Design ? 1," pp. 1-12, 2006.
[20] J. M. Keller and Keller, "Motivational design of instruction," In C. M. Reigeluth (Ed.),Instructional-design theories and models: An overview of their current status. Hillsdale, NJ: Lawrence Erlbaum Associates, 1983.

[21] J. M. Keller, "The use of the ARCS model of motivation in teacher training," In K. Shaw \& A. J. Trott (Eds.), Aspects of Educational Technology Volume XVII: staff Development and Career Updating. London: Kogan Page, 1984.

[22] J. M. Keller, "Development and use of the ARCS model of instructional design," J. Instr. Dev., vol. 10, pp. 2-10, 1987. http://dx.doi.org/10.1007/BF02905780

[23] Bunchball Inc., "Gamification 101: An Introduction to the Use of Game Dynamics to Influence Behavior,” 2010.

[24] R. V Krejcie and D. W. Morgan, "Determining Sample Size For Research Activities, Educational And Psychological Measurement,” Educ. Psychol. Meas., pp. 607-610, 1970.

[25] J. M. Keller and T. W. Kopp, "An application of the ARCS Model of Motivational Design.," in Instructional theories in action Lessons illustrating selected theories and models, 1987, pp. 289320 .

\section{AUTHORS}

W.M. Amir Fazamin W. Hamzah currently is a $\mathrm{PhD}$ student in Computer Science at Universiti Malaysia Terengganu, Malaysia. He received his MSc in Computer Science at Universiti Malaysia Terengganu in 2010. His main research areas are in the fields of e-learning system development, gamification, and computers in human behavior. (E-mail: amirfazamin@gmail.com).

Noraida Haji Ali received her Bachelor, Master degree and $\mathrm{PhD}$ in Computer Science from Universiti Kebangsaan Malaysia in 1995, 1999 and 2012 respectively. She is currently a lecturer at the School of Informatics and Applied Mathematics, Universiti Malaysia Terengganu (UMT). Her current research interests focus on the software engineering area especially in the systems development, Decision-Support System and object-oriented modeling include formal method. (E-mail: aida@umt.edu.my).

Md. Yazid Mohd Saman is a Professor at the School of Informatics and Applied Mathematics, Universiti Malaysia Terengganu (UMT). He received his MSc in Computer Science at Universiti Teknologi Malaysia, and PhD in Computer Science (Parallel \& Distribution Processing) at Loughborough University of Technology, Loughborough, England. His main research areas are in the fields of parallel \& distributed computing (MPI) and network performance modelling. (E-mail: yazid@umt.edu.my).

Mohd Hafiz Yusoff is a lecturer and researcher at School of Informatics and Applied Mathematics, Universiti Malaysia Terengganu (UMT). He earned a Ph.D. in Computing Science from the Newcastle University, UK in 2011. He has worked for several years in the areas of elearning system development and currently working on knowledge management system. (E-mail: hafiz.yusoff@umt.edu.my).

Azliza Yacob is a lecturer and a researcher at Terengganu Advanced Technical Institute University College (TATiUC). She holds a Master of Science (Information Technology - Manufacturing) and a Bachelor of Science (Computer) at University Teknologi Malaysia (UTM). Her main research concentrates on e-learning and Knowledge Management system. (E-mail: azliza@taituc.edu.my).

Submitted 28 December 2014. Published as resubmitted by the authors 24 March 2015. 